\title{
HEDGING BY USING WEATHER DERIVATIVES IN WINTER SKI TOURISM
}

\author{
Bojan S. Đorđević ${ }^{1}$
}

\section{Summary}

Tourism, as one of the main driving forces of economic development, is exposed to many risks. Besides frequent fluctuations in foreign currency exchange, prices of fuel and transportation, the tourism industry has become more sensitive to weather conditions lately. One of the new instruments which can be efficiently used for weather risk hedging is weather derivatives (forwards, futures, options and swaps on chosen weather variables - temperature, rain, snow, wind etc.).

In this paper, we will present the possibility of weather derivatives application in winter tourism - snowfall forwards - in order to hedge the business of ski lift operator company. Our research is based on snowfall data of Kopaonik mountain ski resortand revenues of ski lift operator company. We will show that weather derivatives might be an effective tool for hedging weather risk and reducing the volatility of companies 'revenues in the winter ski tourism business in Serbia.

Keywords: weather derivatives, weather risk, snowfall, hedging, winter ski tourism

JEL: $C 15, G 1, Z 33$

\section{Introduction}

The effects of climate changes and weather conditions on company's business results are increasing, and affecting a growing number of economic sectors. According to MünichRe Group (2000), over $80 \%$ of business activities on a global level are depending on the weather. Most affected sectors are energetics, agriculture, construction, transportation, and tourism (Bank, Wiesner, 2011; Zapranis, Alexandridis, 2013). The companies concerned are the ones that are highly sensitive to weather conditions and seasonality of their operations (Müller, Grandi, 2000a; 2000b). Tourism, as an economic sector, is very sensitive to all kinds of changes, of both economic and noneconomic character (Becken, Hay, 2007; Agrawala, 2008). It is exactly the second type of change, the non-economic one, which is gaining importance lately (for example,

1 Bojan S. Đorđević, full professor, Faculty of Management Zaječar, Megatrend University Belgrade, Park Šuma Kraljevica bb, 19000 Zaječar, phone: +38119430804, e-mail: bojan. djordjevic@,fmz.edu.rs

EP 2018 (65) 1 (125-142) 
safety risk, and climate change and weather risk). As emphasized by Simpson et al. (2008), besides increased exposure and sensitivity to various kinds of risks, modern tourism companies features higher fixed costs and lower profitability. Such structure makes them "slow" in accepting changes, vulnerable under the influence of different sets of risks and affecting the level of tourism service quality (Scott, McBoyle, 2007). Šperanda (2008) suggested that companies operating in tourism sector should eagerly acquire new knowledge and useful tools for risk management, such as, and currently available in our market, currency futures - forwards and swops, which can efficiently manage currency and interest risk.

Weather risk is a product of increasing climate changes, which effects we all feel. Extremely high or low temperatures, droughts and lack of rain, overflow of falls and floods, storms and hurricanes, definitely affect the business of the tourism sector companies. Business protection can be partly found at insurance companies, which cover only specific types of risk when paid compensation for damage in many cases compensates the partial loss. That is why, in order to protect or hedge the loss and reduction of product/service production caused by unfavourable weather conditions, weather derivatives are constructed, as a new tool for risk management (Russ, 2004). As Cao et al. (2004) and Brockett et al. (2005) pointed out, it is about weather risk which presents uncertainty in money flows and revenues as a consequence of non-catastrophic weather conditions (fluctuations in temperature, the quantity of precipitation - rain and snow, thespeed of wind etc.). Edrich (2003) and Ali (2000) made a clear distinction between weather risk and other sources of risk. What is vital here, is that weather risk affects the quantity of demand and sales of certain products/services and not the price of those goods and services. It is all about so-called volumetric risk. The weather condition risk is highly geographically localized and it is not possible to control it. Considering the exposure to weather risk and possibility for hedging, Leggio (2007) concluded that companies usually decide to use weather derivatives in order to lessen the volatility of revenues and money flows, to cover and compensate expenses (companies - hedgers), but also to stimulate and enhance sales (making profits and earnings speculators) (Đorđević, Đorđević, 2014). It is definite that the main motive for trading these derivatives is hedging, but Zapranis and Alexandridis (2013) also emphasized the inevitable motive for profit and existence of speculators, as an important segment of weather derivatives market.

Table 1. Connection between weather and financial risk

\begin{tabular}{|c|c|c|}
\hline SECTOR & WEATHER VARIABLE & RISK \\
\hline Power / Energy industry & Temperature & $\begin{array}{c}\text { Lower sales during warmer winters } \\
\text { and colder summers }\end{array}$ \\
\hline Agriculture / Food Industry & Temperature / Rain / Snow & $\begin{array}{c}\text { Low-yield and loss in periods of } \\
\text { extremely low/high temperatures or } \\
\text { rainfalls }\end{array}$ \\
\hline Beverage producers & Temperature & Lower sales during colder summers \\
\hline
\end{tabular}




\begin{tabular}{|c|c|c|}
\hline SECTOR & WEATHER VARIABLE & RISK \\
\hline Construction & Temperature / Snow & $\begin{array}{c}\text { Delays in work during bad weather } \\
\text { conditions }\end{array}$ \\
\hline Transport and Logistics & Temperature / Rain / Snow & Delays/transport cancellation \\
\hline Tourism / Ski industry & Temperature / Snow & $\begin{array}{c}\text { Reduced revenues during seasons } \\
\text { with temperatures and falls below } \\
\text { average }\end{array}$ \\
\hline Municipality Government & Snow & $\begin{array}{c}\text { Higher costs of snow removal from } \\
\text { city streets when the falls are above } \\
\text { average }\end{array}$ \\
\hline Road Salt Companies & Snow & $\begin{array}{c}\text { Lower incomes during seasons with } \\
\text { weak falls }\end{array}$ \\
\hline
\end{tabular}

Source: Brocket et. al. 2005; Zapranis, Alexandridis, 2013.

Weather derivatives can be defined as future contracts (forwards, futures, options, swaps etc.) that are based on weather index on chosen weather variable (temperature, rain, snow, wind etc.) (Jewson, Brix, 2005; Hull, 2009; Lazibat et al., 2010). Weather index gains its value by quantification of recorded weather condition deviation from chosen reference point (weather station), where deviation calculation is based on real weather conditions observation for a certain period and where each level of divergence (for example $1^{\circ} \mathrm{C}, 1 \mathrm{~mm}$ of rain or $1 \mathrm{~cm}$ of snow) obtains its tick size (tick) (Jewson, Brix, 2005). Depending on type and position taken (buying or selling), the contract becomes valuable when the value of index falls or rises above strike level. This way, weather conditions turn into tradable goods (VanLennep et al., 2004; Veselinović et al., 2014). Like other financial instruments, weather derivatives are traded in theorganized market stock exchanges (standard contracts), but also out of the market (over the counter - OTC), in arrangement with traders - banks, insurance houses, hedge funds etc. (Marković, 2013; Đorđević,Đorđević, 2014). If the trade is in an organized market, then we are talking about futures, while forwards and swaps are usually traded in OTC. Weather options are present at both markets, and they usually contain chosen weather index in their bases. The biggest and most important weather derivative market today is American CME, while in Europe it used to be London market LIFFE, known today as ICE Europe.

Forward represents a simple contract which, at given time, arranges purchase and sale of certain assets at some future time point, where commitments are realized in the future, i.e. on a previously set date. One side (forward buyer) hedges from an eventual rise of assets price, while the other side (forward seller) protects from the fall of assets price (Hull, 2009; 2011). Forwards are not standardized contracts, which mean that they are traded on OTC markets, with the mutual agreement of both sides on all elements of the contract (contract price, maturity date). Basic motive for forwards trading is protection (hedging) from markets' risk and final delivery of assets on the set date. These contracts are not liquid, meaning that they cannot be re-sold, thus they are not speculative (Đorđević, Đorđević, 2013; 2014). Compared to other derivatives, forwards have both advantages 
and disadvantages. They are very flexible because they are adjusted toboth sides and have small transaction cost. Disadvantage refers to the absence of clearing house in the trade, so the risk of contract realization is growing. Also, if there is no margin (which is the case with futures), this type of contract exposes traders to credit risk (Golden et al., 2007). In case of weather derivative, forward would contain weather index in its base on certain weather variable (temperature, rain, snow, wind, frost etc.). On weather derivative market forwards usually appear in the form of swap contracts (Marković et al., 2012). Contractors would be obliged to set the elements for construction of weather forward precisely: weather index with variable, index unit value - tick, reference meteorology station - weather station, strike level, upper and lower limit - $\mathrm{L}_{\text {lower }}$ and $\mathrm{L}_{\text {upper }}$ maximum pay off - maxPayOff, validity period, due date and margin, in order to lessen credit risk (for example $5-10 \%$ of contract value).

Today, weather derivatives represent a device in weather risk management, and their usage in the world is increasing, mostly in options trading. Since weather derivatives present general uncertainty in our region, apart from few works on the subject of their application in agriculture, this paper aims to show the possibility of hedging by applying chosen weather derivatives (snowfall forward) in winter ski tourism, on an example of ski lift operator in Kopaonik.

The paper is structured as follows: in section 2, we define the problem and the aims of our research. In section 3 we give an overview of most significant research results on the subject of weather risk management and derivatives application in winter ski tourism, ski resorts and ski lift operator business. In section 4 we present research methodology, data collection and results. In this section, werepresent analyses of hedge effectiveness when forwards are applied to snowfall index (weather snowfall forward) in ski lift operator business in Kopaonik mountain. Eventually, section 5 gives conclusions and recommendations for future research.

\section{Defining research problem and aims}

Ski season in Kopaonik ski resort lasts from December until the end of April (winter ski season). In that period ski resort, that is ski lift operator, makes amajor and most significant share of its incomes from ski tickets sales and ski lift operations. During a winter season, when the profits are the highest, the quantity of snowfalls and height of natural snow on ski tracks is of great importance, excluding artificial snow systems, which efficient work depends on the temperature (it takes from at least $-2,5^{\circ} \mathrm{C}$ up to $-5^{\circ} \mathrm{C}$ for snowmaking system to work efficiently). Due to climate changes, which in our case can be summed up to extreme weather (un)conditions (insufficient or overflowing snowfalls), the exposure of ski resorts and their income to weather risk is growing. In order to ensure their business and protect (hedge) from potential losses, ski operator can use weather derivative with weather index on snowfalls in their base. World markets (for example CME) offer monthly and seasonal weather derivatives (forwards, futures, options, and swaps), which appear in both organized (standardized contracts) and OTC markets. In weather-sensitive and seasonal industries, such as tourism, monthly and seasonal optional contracts on 
various weather variables (temperature, falls - rain, snow, frost etc.) are widely used. In winter tourism, dominant weather variable is snowfall quantity in ski season, although we shouldn't neglect temperature and wind, on whose index base ski resorts can also trade.

In this paper, we presumed that the quantity of snowfall highly affects incomes from ski tickets during the winter ski season at Kopaonik mountain. Ski lift operator (in our case JP Skijališta Srbije) wants to ensure (hedge) its business and ski ticket sales profits from weather risk of insufficient snowfall during the season (financial hedging), without taking into consideration existing artificial snowmaking system, so that operational hedging is not considered. Let us assume that weather derivatives on a quantity of snowfall are available at OTC market. Ski lift operator chooses weather forward, or seasonal snowfall index forward, to be more precise. Snowfall quantity data is gained from Kopaonik weather station, which is settled in Sunčana dolina (Sunny Valley) so that geographical basis risk is avoided, while the inclusion of basis risk will depend on a correlation of weather index with snowfall and ski ticket sales revenue. Basis risk will be included as the most important element of snowfall forward hedging effectiveness, as a coefficient of simple linear regression of income value and snowfall weather index (Castelino, 1992; Rohrer, 2004).

When evaluating weather forward, we will use the simplest and at the same time efficient method for price setting - method of historical simulation, which is based on historical data of Kopaonik snowfall for the past 10 years. As Hnilica (2007)ascertained, a method of historical simulation represents a simple model for weather derivative evaluation and a base for further statistical analyses, with the assistance of appropriate software (Crystal Ball, for example).

Therefore, we have two goals: firstly, we want to show that there is a statistically significant connection between snowfall and ski lift operators' income, and secondly, we'd like to analyze forward implementation effect in hedging weather risk and reduction of weather risk in ski lift operators' business at Kopaonik.

\section{Literature review}

The largest number of weather derivatives implementation research is found in the agriculture sector, while in tourism that is not a case. Researching winter ski tourism, most researchers focused on basic questions of climate changes and snowfall influence on tourism companies business and tourists' behaviour. Thus, researching the connection between lack of snow, skier's activities and ski ticket sales in winter resorts in Switzerland, Austria and Slovakia, certain authors came to conclusions about statistically significant influence of snowfall and weather conditions on ski ticket sales and activity of skiers on the tracks (Shin et al., 2009; Toeglehoher et al., 2011). In his research on activities of domestic and foreign visitors of winter resorts, Falk (2013) discovered significantly higher sensitivity of domestic visitors to weather condition changes in relation to foreign tourists, which led to different behaviour and activities on ski tracks. Toeglehoher et al. (2012) presented a new model for measuring weather risk and business sensitivity to weather conditions - Weather-VaR. Their research was 
based on 20-year snowfall data and ski centre Kitzbuehel (Austria) operations, which led to conclusions about significant possibilities of VaR methodology application in weather risk management.

The most important (and available) research results of weather derivative application in winter tourism are gained from examples of ski resorts in Austrian and Italian Alps. Bank and Wiesner (2011) looked into the possibility of efficient weather derivative application in Austrian winter centres. Interviewing 61 ski lift operators, they got results of significant possibilities of derivative application, in order to reduce the lack of natural snow risk and protect themselves from business loss. Piovani et al. (2012) and Sileo (2012) analyzed weather derivative application and hedging efficiency implementing weather put option in ski operator business in winter centre Andalo in Italian Alps. Referring to methodologysuggested by Beyazit and Koç $(2010 ; 2012)$, based on data from a ski center in Turkey, they constructed parameters, defined the most suitable model to determine the price of selling option, and established significant possibilities to apply options in order to reduce risk from ski resorts revenue decline, due to the lack of natural snow. Given results were affirmed by Franzoni and Pelizziari (2016). Tang and Jang $(2012 ; 2016)$ in their works constructed and presented snowfall forward as an efficient instrument for ski resort business hedging, calculating hedge effectiveness. Named authors emphasized the importance of geographical basis risk as the most significant derived element of derivative which highly affects the effectiveness of forward hedging, but only when the construction of multiple property resorts is in question (in order to construct one unique derivative, so-called basis derivative, Skijališta Srbije would need snowfall data and business data for Kopaonik, Zlatibor, and Stara Planina ski resorts). As Castelino (1992) and Rohrer (2004) pointed out, basis risk is the most significant data in the construction of a weather hedge. Analyzing geographic, calendar and production basis risk, they concluded that given basis risks are much more important than correlation coefficient, but only in case of a spatial distance of hedged locations and meteorological stations (Considine, 2000; Golden et al., 2007, Yang et al., 2009).

Based on formerly presented studies, it is evident that all researchers emphasize the significant influence of weather variables (snowfall) on business results of world's ski resorts, as well as positive results of derivative's hedging. Since these kinds of studies haven't been conducted in our region so far, it is our task to ascertain to what extent ski centre's business depends on snowfall quantity, to present weather derivative as a new risk management tool and to measure the effectiveness and efficiency of chosen derivative hedging.

\section{Research methodology and results}

To investigate the possibility of efficient weather risk derivative hedging, we must go through several steps: 1. Weather index determination (snowfall index - SFI), 2. Investigation of ski resort revenue dependence on tickets sales based on snowfall quantity (regression and correlation analyses, autocorrelation test and test of heteroscedasticity), 3. Construction of chosen weather derivative (weather snowfall forward), and 4. Evaluation of snowfall forward hedging effectiveness. 


\section{Weather index determination}

In our research we will use cumulative snowfall index - CumSFI, corresponding to the sum of overall monthly falls during winter skiing season at Kopaonik ( $1^{\text {st }}$ December $30^{\text {th }}$ April). We generate CumSFI as follows:

$$
\text { CumSFI }=\sum_{t=1}^{x} y_{t}
$$

Where we have

- $\quad x$ - length of cumulative period ( $\left(1^{\text {st }}\right.$ December $-30^{\text {th }}$ April)

- $\quad y_{t}$-quantity of snowfalls on day $t$

In order to calculate weather index, we need data about snowfalls measured at Kopaonik. Historical daily data are gained from RHMZ Serbia measuring station Kopaonik at Sunny Valley, for the 1997-2015 periods. Since companies prefer season contracts when trading weather derivatives, we would need data about the quantity of snowfall for certain winter seasons. The contracts that cover the period from $1^{\text {st }}$ November till $30^{\text {th }}$ April are most traded on the markets. In this work, we will use the overall snowfall quantity in winter seasons $(2006 / 2007$ - 2015/16), which in our case represent season cumulative indices CumSFI for Kopaonik ski resort. Named period of 10 winter seasons has been chosen because this period had available data about income generated from ski tickets sales in given ski resort, which is Kopaonik ski operator. Cumulative index CumSFI presents overall snowfalls data in five months period (December - April). Snowfalls, as well as ski resort monthly income from ski tickets in November, are excluded because ski resort opens from $1^{\text {st }}$ December. Snowfalls and incomes from ski tickets are shown in Figure 1.

Figure 1. Snowfalls by ski seasons and ski tickets incomes of ski operating company

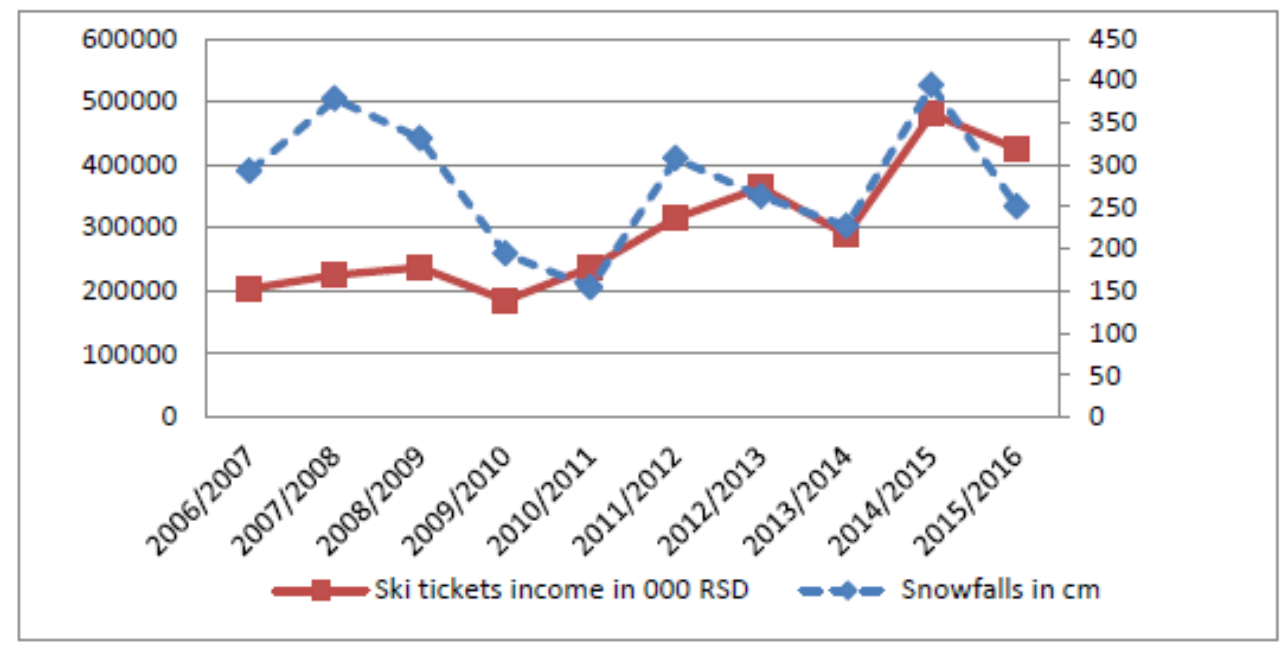

Source: Author

EP 2018 (65) 1 (125-142) 


\section{Regression model and standard assumption model review}

Analyses of those two separate variables (snowfall quantity as an independent variable $-x$, and the amount of ski lift operator's revenue generated from ski tickets, as a dependent variable $-y$ ) connection are based on simple linear regression model and equation:

$$
y=a+\beta x+\varepsilon
$$

Where is:

$a$ - constant of model

$\beta$-evaluation of regression coefficient with independent variable $\mathrm{x}$ (quantity of snowfalls)

$\varepsilon$ - residual of model

Model is based on results of data analyses published in reports on ski tickets sale in winter centre Kopaonik, as well as on report of referent meteorological station in Sunny Valley on snowfalls for season 2006/07 up to 2015/16. Data are given on monthly level for December, January, February, March and April.

Coefficient $\beta$ is the most important parameter for us because it shows the change of dependable $y$ (ski resort income from ski tickets sales) when the independent $x$ (quantity of snowfall) changes per 1 unit, that is $1 \mathrm{~cm}$. The value of this coefficient will be of importance when constructing weather derivative, i.e. determination of its tick size.

Evaluation of set regression model will be reliable only if standard assumption model is fulfilled. Otherwise, the evaluation of regression coefficient would be biased. That is why it is necessary to examine several assumption models. The first assumption that needs to be fulfilled is testing residual homoscedasticity and heteroscedasticity. We will use Breusch - Pagan / Coock - Weisberg test. It is assumed that residual variance is constant $\left(\mathrm{H}_{0}\right)$. The result Prob $>\chi^{2}=0.423$ is telling us that model has no expressed heteroscedasticity, that is, there is no significant difference of random error variances.

The second assumption is related to residual autocorrelation. We use Durbin - Watson test $(D W)$. At significance level $\alpha=0.05$ and observation number $n=50$, with one regression variable, we have limit table values $d_{l}=1.503$ and $d_{u}=1.585$. Based on carried out $D W$ test we gained autocorrelation coefficient $d=1.009<d_{l}=1.503$. We reject $H_{0}$ and conclude there exist a positive residual autocorrelation. In order to remove autocorrelation, we have implemented Cohrane - Orcutt model. The result is the transformed value of $D W$ test $\left(d=1.625>d_{u}=1.585\right)$, thus we accept $\mathrm{H}_{0}$ and conclude that autocorrelation in the model has been removed.

Gained coefficient evaluation forms final regression model of the influence of snowfalls on ski lift operator's ticket sale sincome. The results gained by regression and correlation analyses are shown in Figure 2. and in Table 2. 
Figure 2. Snowfall and ticket income regression and correlation coefficient

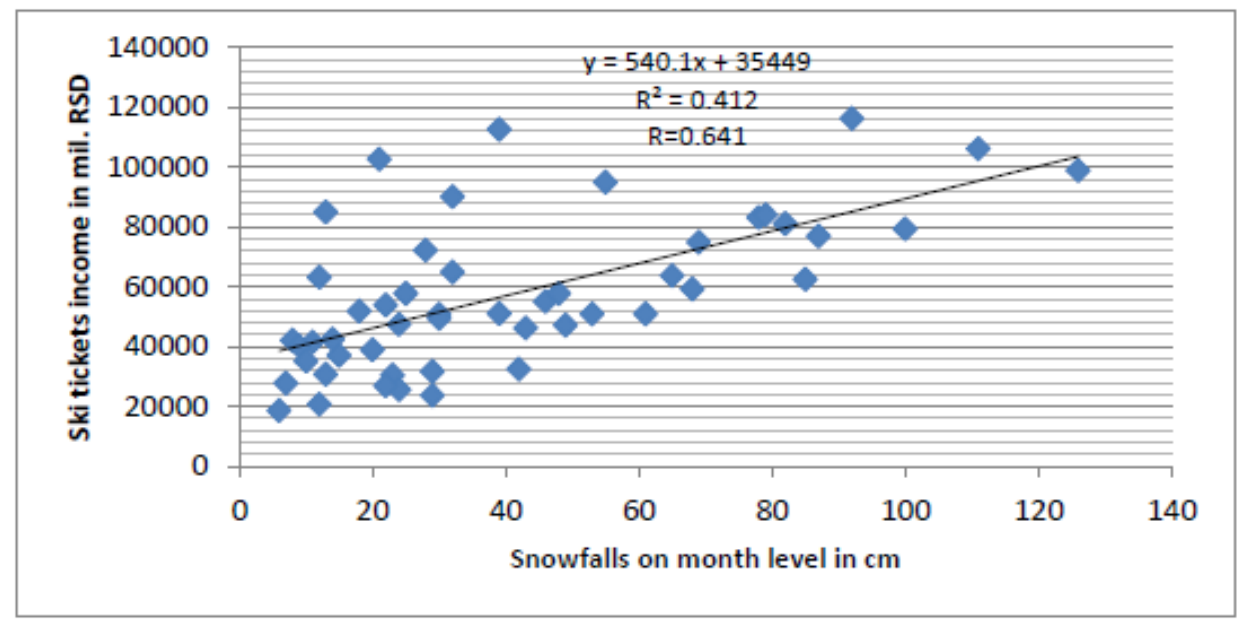

Source: Author

Table 2. Monthly results of statistical analyses for winter seasons 2006-2016.

\begin{tabular}{|l|l|l|l|l|l|l|}
\hline & \multicolumn{1}{|c|}{ December } & \multicolumn{1}{|c|}{ January } & \multicolumn{1}{|c|}{ February } & \multicolumn{1}{|c|}{ March } & \multicolumn{1}{c|}{ April } & \multicolumn{1}{c|}{ Season } \\
\hline Snowfall & $203^{*}$ & 383 & 614 & 636 & 310 & 214.6 \\
\hline Mean & 20.3 & 38.3 & 61.4 & 63.6 & 31 & 42.92 \\
\hline St.dev. & 9.821179 & $\mathbf{2 4 . 2 1 2 2 6}$ & $\mathbf{3 4 . 5 9 6 7 2}$ & $\mathbf{2 9 . 7 1 0 4 5}$ & 20.72572 & 97.01569 \\
\hline Variance & 96.45556 & 586.2333 & 1196.933 & 882.7111 & 429.5556 & 9412.044 \\
\hline Income & & & & & & \\
\hline Mean & 50861.8 & 60766.5 & 71198.9 & 74000.1 & 31872.2 & 288699.5 \\
\hline St.dev. & 17419.12 & $\mathbf{2 4 2 4 6 . 9 2}$ & $\mathbf{2 6 5 1 9 . 3 5}$ & $\mathbf{2 2 5 8 7 . 7 2}$ & 12520.33 & 92157.44 \\
\hline Variance & $3.03 \mathrm{E}+08$ & $5.88 \mathrm{E}+08$ & $7.03 \mathrm{E}+08$ & $5.1 \mathrm{E}+08$ & $1.57 \mathrm{E}+08$ & $8.49 \mathrm{E}+09$ \\
\hline$\rho$ & 0.075873 & $\mathbf{0 . 8 1 3 8 7 2}$ & $\mathbf{0 . 7 0 1 8 3 1}$ & $\mathbf{0 . 5 8 8 8 5}$ & 0.884855 & $\mathbf{0 . 6 4 1 8}$ \\
\hline
\end{tabular}

Source: Author

Note: *CumSFI in cm

Evaluating regression and correlation analyses results, we can conclude the following: determination coefficient $\mathrm{R}^{2}=0.4119$ (adjust $\mathrm{R}$ square $=0.3997$ ) is leading us to a conclusion that $41.19 \%$ of the overall variability of ticket income is explained by snowfall quantity. The remaining $58.81 \%$ is not explained by regression and is influenced by unidentified factors. Correlation coefficient $\mathrm{R}=0.6418$ indicates directly expressed linear stochastic relation between snowfall and ticket income. Finally, we can present linear regression equation of snowfall and ticket income connection $y=f(x)$ :

$$
y=540.145 x+35448.56+19726.88
$$

The most significant data in Table 2. are standard deviation and variance of snowfall and incomes during given months, which present a measure of risk, i.e. ski resort weather risk income volatility. We can see that highest values of standard deviation are achieved for January, February, and March when ski resort generates most of its income. This EP 2018 (65) 1 (125-142) 
is the most important information for ski resorts when it comes to decision making about contracting certain monthly derivative in order to hedge, regardless of its type (forwards, futures or options).

\section{Construction of weather snowfall forward}

Let us assume that ski lift operator wants to hedge from the lack of snowfall. For this purpose, weather forward on snowfall index is arranged, with strike level $S L=$ $214.6 \mathrm{~cm}$ of snow. Ski lift operator holds a short position in this contract. The payoff is expected in acase that CumSFI $<S L$, i.e. $(S L-C u m S F I) \times T$.

The other contractor, let's say an insurance house,for example, holds a long position and any snowfall quantity bigger than $S L(214.6 \mathrm{~cm})$ is in order since the house will be expecting a payoff in the value of $(C u m S F I-S L) \times T$.

Weather forward value is gained through the following formula (short position):

Where is

$$
\begin{array}{ll}
- & S L-\text { strike level } \\
\text { - } & \text { Cum } S F I-\text { cumulative snowfall index } \\
\text { - } & T-\text { tick value (weather index unit value in money) } \\
\text { - } & e^{-r t}-\text { discount factor } \\
\text { - } & r-\text { interest rate (interest rate on capital markets in Serbia }-4 \%) \\
\text { - } & t \text { - maturity period (5 months) }
\end{array}
$$

The weather index unit value $T$ is gained based on regression equation coefficient and snowfall average in given time. Mathematical calculation shows $T=11.000 € / \mathrm{cm}$ of snowfalls. Since the trading takes place on OTC market, we assume that both buyer and seller of weather forward agreed on the $T$ money value.

Basic elements in the construction of weather forward are weather index (CumSFI), the weather index unit value in money (tick $-T)$, strike level $(S L)$, maturity period $t$, interest rate $-r$, and reference climate point or measuring station. Since forwards are traded on bilateral, OTC market, it is up to contracting parties (buyer and seller) to agree upon all named elements. In this case, there is a possibility of arranging a monthly, several months or seasonal forward on snowfall. Depending on the maturity period (monthly or season), we get strike level $S L$, which presents snowfall average for a certain period (Mean). The elements of weather forward are shown in Table 3.

Table 3.Basic elements of seasonal and monthly snowfall forward of Kopanik ski resort

\begin{tabular}{|l|c|c|}
\hline \multicolumn{3}{|c|}{ Weather Snowfall Forward } \\
\hline Type of contract & OTC Seasonal Forward & OTC Monthly Forward \\
\hline Weather index & Seasonal CumSFI & Monthly CumSFI (February) \\
\hline Meteorological station & Kopaonik Sunny Valley & Kopaonik Sunny Valley \\
\hline Time & 5 months & 1 month \\
\hline
\end{tabular}




\begin{tabular}{|l|c|c|}
\hline Tick value & $11.000 € / \mathrm{cm}$ & $11.000 € / \mathrm{cm}$ \\
\hline Strike level & $214.6 \mathrm{~cm}$ & $61.4 \mathrm{~cm}$ \\
\hline PayOff limit* & $214.6 \mathrm{~cm}$ & $61.4 \mathrm{~cm}$ \\
\hline Interest rate & $4 \%$ & $4 \%$ \\
\hline MaxPayOff & $2.32 \mathrm{mil} . €$ & $672.700 €$ \\
\hline
\end{tabular}

Note:* In our case, payoff limit is at strike level. In bilateral OTC contracts, it is possible to arrange both upper and lower payoff limit, which is mostly the case with weather swaps. In such case, lower and upper limit would be set $S L+/-\sigma$ (st.dev.)

\section{Hedging effectiveness evaluation}

Hedging effectiveness - HE, is evaluated based on several elements: 1 . Revenue value without hedging - $\mathrm{VR}_{\mathrm{UNHEDGED}}, 2$. Value of hedged revenue - $\mathrm{VR}_{\text {HEDEGED }}, 3$. Hedge ratio $h, 4$. Strike level - $S L$, and 5. Value of payoff - PayOff. Those elements are gained based on following equations:

$\mathrm{VR}_{\text {HEDGED }}=\mathrm{VR}_{\text {UNHEDGED }}+$ PayOff

PayOff $=h \times(S L-C u m S F I)$

Hedge ratio $-h$ or optimum indicator of hedger minimum variance, i.e. ski resort, is gained by following formula (Hull, 2011; Rao, Thakur, 2008, Gupta, Kaur, 2015):

$h=\rho$

Where is

$\rho$ - correlation coefficient of income change $\Delta \mathrm{R}$ and snowfall change $\Delta \mathrm{S}(\rho=0,30)$

$\sigma_{\Delta R}-$ standard deviation of snowfall quantity change $\left(\sigma_{\Delta s}=35,37\right)$

Hedging effectiveness is gained on the base of formula (Ederington, 1979; Tang, Jang, 2012, Gupta, Kaur, 2015):

$$
\mathrm{HE}=1-
$$

Results of weather forward hedging effectiveness for the past 10 winter seasons at Kopaonik are shown in Table 4.

Table 4. Hedging effectiveness using weather snowfall forward

\begin{tabular}{|l|r|c|c|c|}
\hline Ski season & CumSFI & $\begin{array}{c}\text { Unhedged Revenue } \\
\text { (million } \boldsymbol{\epsilon} \text { ) }\end{array}$ & PayOff & $\begin{array}{c}\text { Hedged Revenue } \\
\text { (million } \boldsymbol{\epsilon} \text { ) }\end{array}$ \\
\hline $2006 / 07$ & 180 & 1.776 & 0.066 & 1.842 \\
\hline $2007 / 08$ & 222 & 2.105 & -0.014 & 2.090 \\
\hline $2008 / 09$ & 251 & 2.156 & -0.069 & 2.086 \\
\hline $2009 / 10$ & 145 & 1.462 & 0.133 & 1.595 \\
\hline $2010 / 11$ & 77 & 1.749 & 0.264 & 2.013 \\
\hline $2011 / 12$ & 332 & 2.942 & -0.225 & 2.717 \\
\hline $2012 / 13$ & 304 & 2.808 & -0.171 & 2.673 \\
\hline
\end{tabular}




\begin{tabular}{|c|c|c|c|c|}
\hline Ski season & CumSFI & $\begin{array}{c}\text { Unhedged Revenue } \\
\text { (million } € \text { ) }\end{array}$ & PayOff & $\begin{array}{c}\text { Hedged Revenue } \\
(\text { million } €)\end{array}$ \\
\hline $2013 / 14$ & 88 & 1.986 & 0.243 & 2.229 \\
\hline $2014 / 15$ & 356 & 3.895 & -0.271 & 3.624 \\
\hline $2015 / 16$ & 191 & 3.175 & 0.045 & 3.220 \\
\hline Mean $-\mu$ & 214.6 & 2.4054 & $4.16 \mathrm{E}-18$ & 2.4089 \\
\hline St.dev. $-\sigma$ & 97.01569 & 0.767866 & 0.18595 & 0.639261 \\
\hline Variance $-\sigma^{2}$ & 9412.044 & 0.589618 & 0.034577 & 0.408655 \\
\hline Hedge Ratio - $\mathrm{h}$ & & & & 0.00192 \\
\hline $\mathrm{HE}$ & & & & $0.308(30.8 \%)$ \\
\hline
\end{tabular}

Source: Author

Analyzing basic financial business results we'll be given a more comprehensive view of economic-financial effects of trading forward in ski resort operations, including variable costs - $V_{c}$, cover margin or ski ticket income - $M_{p s}$. The effects on ski resort operations are considered in cases $\mathrm{VR}_{\text {HEDGED }}$ and $\mathrm{VR}_{\text {UNHEDGED }}$. Relations are as follows:

$M p s=V R-V C$

$M p s^{U N H E D G E D}=\mathrm{VR}_{\mathrm{UNHEDGED}}-V c$

$M p s^{H E D G E D}=\mathrm{VR}_{\mathrm{HEDGED}}-V c$

Obtained results are shown in Table 5.

Table 5. Hedge effectiveness and risk reduction with variable costs

\begin{tabular}{|c|c|c|c|c|c|c|}
\hline Ski season & CumSFI & $\begin{array}{l}\text { VR }_{\text {UNHEDGED }} \\
\text { (million } € \text { ) }\end{array}$ & $\begin{array}{l}\mathrm{VR}_{\text {HEDGED }} \\
(\text { million } €)\end{array}$ & Ve & Mps $^{\text {UNHEDGED }}$ & Mps ${ }^{\text {HEDGED }}$ \\
\hline $2006 / 07$ & 180 & 1.776 & 1.842 & 0.736 & 1.04 & 1.106 \\
\hline $2007 / 08$ & 222 & 2.105 & 2.090 & 0.627 & 1.478 & 1.463 \\
\hline $2008 / 09$ & 251 & 2.156 & 2.086 & 0.420 & 1.736 & 1.666 \\
\hline $2009 / 10$ & 145 & 1.462 & 1.595 & 0.720 & 0.742 & 0.875 \\
\hline $2010 / 11$ & 77 & 1.749 & 2.013 & 0.853 & 0.896 & 1.16 \\
\hline $2011 / 12$ & 332 & 2.942 & 2.717 & 0.665 & 2.227 & 2.052 \\
\hline $2012 / 13$ & 304 & 2.808 & 2.673 & 0.633 & 2.175 & 2.04 \\
\hline $2013 / 14$ & 88 & 1.986 & 2.229 & 0.734 & 1.252 & 1.495 \\
\hline $2014 / 15$ & 356 & 3.895 & 3.624 & 1.120 & 2.775 & 2.504 \\
\hline $2015 / 16$ & 191 & 3.175 & 3.220 & 1.768 & 1.407 & 1.452 \\
\hline Mean $-\mu$ & 214.6 & 2.4054 & 2.4089 & 0.8276 & 1.5728 & 1.5813 \\
\hline St.dev. $-\sigma$ & 97.01569 & 0.767866 & 0.639261 & 0.375634 & 0.652695 & 0.497878 \\
\hline Variance $-\sigma^{2}$ & 9412.044 & 0.589618 & 0.408655 & 0.141101 & 0.42601 & 0.247882 \\
\hline $\begin{array}{l}\text { Hedge Ratio- } \\
\mathrm{h}\end{array}$ & \multicolumn{4}{|l|}{0.00192} & & \\
\hline $\mathrm{HE}$ & \multicolumn{4}{|c|}{ 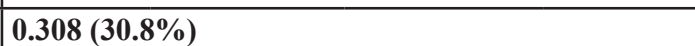 } & \multicolumn{2}{|l|}{$0.420(42 \%)$} \\
\hline
\end{tabular}

Source: Author

Table 5. shows that with use of forward, there is evidently significant reduction of hedger's (ski lift operator) exposure to weather risk. For CumSFI ranging from $77 \mathrm{~cm}$ 
up to $356 \mathrm{~cm}$ snowfall, standard deviation $(\sigma)$ and variance $\left(\sigma^{2}\right)$ of net ski ticket income are reduced by $23.77 \%$. If we observe results based on net ski ticket income $-M p s$, the results of hedging are even better - we can note hedge effectiveness rise by $39 \%$. We can say that obtained results are in accordance with recent results of derivative hedge effectiveness research in European ski centres (risk reduction and ski ticket income volatility decrease by 28\%) (Leggio, 2007; Tang, Jang 2012; Sileo, 2012).

If we look at the variable costs values $-V_{c}$, we can see higher values next to CumSFI lower values. The explanation lies in greater use of snowmaking system, which the ski lift operator is using if there is the lack of natural snow. According to Kopaonik ski resort, an optimum level of snow on the ski track is $30 \mathrm{~cm}$ for daily use, with a maximum temperature of $-2,5^{\circ} \mathrm{C}$ needed for efficient system operation. For example, during 2007/08 season, Kopaonik ski resort made $300.000 \mathrm{~m}^{3}$ of artificial snow (average of $33 \mathrm{~cm}$ of snow on the tracks) with costs of $20,00 \mathrm{RSD} / \mathrm{m}^{3}(6,6$ million RSD). If we have in mind that CumSFI $=222 \mathrm{~cm}$ in that season (more than the historical average of $214.6 \mathrm{~cm}$ ), we can conclude that ski resort was forced to use snowmaking systems during certain periods, which affected the growth of $V_{c}$.

\section{Conclusion}

We have presented seasonal weather forward as a new and efficient tool for weather risk financial hedging. Our research was focused on analyses of a possible implementation of snowfall forward in ski lift operator business at Kopaonik mountain ski resort, in order to reduce the lack of snowfall risk and ski ticket income volatility decrease. Using basic techniques of risk management we can achieve more than expected ski ticket income hedging effectiveness by over $40 \%$. Considering the fact that companies have a different understanding of risk and aversion to risk, this paper presents in what way and with what kind of hedging strategies (short and long hedge) tourism companies can control such risk. In our example, we used the dominant variable for winter ski tourism - snowfall, but we must also emphasize the possibility of using a temperature-based index derivative, which can be of importance for ski centre operative hedging, i.e. for snowmaking system.

This research is based on weather snowfall forward as basic and most simple future contract. Besides its advantages, we must point out some operational flaws of forward, which are reflecting in higher level of credit risk, insufficient liquidity (not transferable) and difficulties to find the other partner in OTC trading. Therefore, tourism companies have liquid contracts, such as futures and options, available, both standardized (exchange-traded derivatives) and in OTC market. The stock exchange is offering contracts which are monthly and seasonal. In this paper, besides seasonal, we have shown monthly digression of snowfall index and incomes, which make a basic data for the potential choice of weather derivative and construction of the same.

Given results are the foundation for further exploration of possibilities and effectiveness of weather derivatives application in winter ski tourism in Serbia. Since there haven't 
been any researches of this kind, author's intention was to explore the options of implementation and weather option effects in Kopaonik ski resort in a future period, as well as in other ski resorts - Zlatibor and Stara Planina. This will enable an overview of geographic diversification - geographical basis risk and construction of weather basis derivative, based on chosen contract - forward, future or option. It is up to companies in winter tourism sector to keep track of new discoveries, inspect all possibilities and be prepared for timely reaction in terms of greater exposure to different kinds of risk. They already have different strategies of financial and operative hedging at their disposal.

\section{Literature}

1. Agrawala, S. (2007): Climate Change in the European Alps: Adapting Winter Tourism and Natural Hazard Management, Organization for Economic Cooperation and Development Publications, Paris, France.

2. Ali, P.U. (2000): Weather Derivatives, Hedging Volumetric Risk and Directors Duties, Company and Securities Law Journal, no. 18, pp. 151-155., Law Book Co., Sidney, Australia.

3. Bank, M., Wiesner, R. (2011): Determinants of weather derivatives usage in the Austrian winter tourism industry, Tourism Management,vol. 32, no. 1, pp. 62-68., Elsevier.

4. Becken S., Hay J. (2007): Tourism and Climate Change - risks and opportunities, Channel View Publications, clClevedon, UK.

5. Beyazit, M.F., Koç, E. (2010): An Analysis of Snow Options for Ski Resort Establishments, Tourism Management, vol. 31, no.5, pp. 676-683., Elsevier.

6. Beyazit, M.F., Koç, E. (2012): Using Weather-Related Derivative Products for Tourism and Hospitality Businesses, in Visions for Global Tourism Industry - Creating and Sustaining Competitive Strategies, Murat Kasimoglu (Ed.), pp. 225-246., InTech Open Science (available at: ww.academia.edu/2658840/Beyazit_M._F. and_Koc_E._2012_Using_Weather-Related_Derivative_Products_for_Tourism_ and_Hospitality_Businesses_in_Visions_for_Global_Tourism_Industry_Ed._M. Kasimoglu_InTech_Open_Science_225-246)

7. Brockett, P.L., Wang, M., Yang, C. (2005): Weather Derivatives and Weather Risk Management, Risk Management and Insurance Review, vol. 8, no. 1, pp. 127-140, American Risk and Insurance Association, USA.

8. Brockett, P.L., Golden, L., Yang, C., Zou, H., (2008): Addressing Credit and Basis Risk Arising from Hedging Weather-Related Risk with Weather Derivatives, ASTIN 2008 Symposium of International Actuarial Institute, Manchester, England, July 12-16., 2008. (available at:http://www.actuaries.org/ASTIN/Colloquia/Manchester/ Papers/brockett paper_final.pdf)

9. Cao, M., Wei, J. (2004): Weather Derivatives Valuation and Market Price of Weather Risk, Journal of Futures Markets, vol.24, no.11, pp.1065-1089., Wiley Periodicals Inc., USA (available at: http://citeseerx.ist.psu.edu/viewdoc/download?doi=10.1.1. $\underline{453.6125 \& \text { rep }=\text { rep } 1 \& \text { type }=\text { pdf) }}$ 
10. Castelino, M.G. (1992): Hedge Effectiveness: Basis Risk and Minimum - Variance Hedging, Journal of Futures Markets, vol. 12, no. 2, pp. 187-201., Wiley Periodicals Inc., USA.

11. Considine, G. (2000): Introduction to Weather Derivatives, Weather Derivatives Group, Aquila Energy (available at: www.cme.com/files/introweather.pdf)

12. Đorđević, B., Đorđević, M. (2013): Hedžing primenom fjučersa - za i protiv, Bankarstvo, vol. 42, br.2, str. 150-177., Udruženje banaka Srbije, Beograd, Srbija.

13. Đorđević, B., Đorđević, M. (2014): Vremenski derivati - instrument zaštite poslovanja od vremenskih rizika, Bankarstvo, vol. 43, br. 6, str. 156-179., Udruženje banaka Srbije, Beograd, Srbija.

14. Edrich, C. (2003): Weather risk management, Journal of Financial Regulation and Compliance, vol.11, no. 2, pp. 164-168., Emerald Publishing, UK.

15. Ederington L. H. (1979): The Hedging Performance of The New Futures Markets, Journal of Finance, vol. 34, issue 1, pp. 157-170., American Finance Association, USA.

16. Franzoni, S., Pelizzari, C. (2016): Weather Risk Management in Tourism Industry, Symphonia Emerging Issues in Management, no.1, ISTEI, Milan, pp.45-55. (available at: http://symphonya.unimib.it/article/view/2016.1.05 franzoni.pelizzari)

17. Falk, M. (2013): A Survival Analysis of Ski Lift Companies, Tourism Management, vol. 36, pp.377-390., Elsevier.

18. Golden, L.L., Wang, M., Yang, C. (2007): Handling Weather Related Risks Through The Financial Markets: Considerations of Credit Risk, Basis Risk and Hedging, Journal of Risk and Insurance, vol. 74, no. 2, pp. 319-346., American Risk and Insurance Association, USA.

19. Gupta, K., Kaur, M. (2015): Impact of Financial Crisis on Hedging Effectiveness of Futures Contract: Evidence from The National Stock Exchange of India, South East European Journal of Economics and Business, vol. 10, no. 2, pp. 69-88., The Journal of University of Sarajevo, Bosnia and Herzegovina (available at: https:// www.degruyter.com/downloadpdf/j/jeb.2015.10.issue-2/jeb-2015-0009/jeb-20150009.pdf)

20. Hnilica, J. (2007): Crystal Ball in Weather-Linked Derivatives Valuation, The 2007 Crystal Ball User Conference, Denver, USA

21. Hull, J. (2009):Options, Futures and Other Derivatives, $7^{\text {th }}$ ed., Pearson Education, New Jersey, USA.

22. Hull, J. (2011): Fundamentals of Futures and Options Markets, Global Edition, Pearson, London, UK.

23. Jewson, S. (2004): Introduction to Weather Derivative Pricing, The Journal of Alternative Investments, vol. 7, no.2, pp. 57-64., Chartered Alternative Investment Analyst Association, USA.

24. Jewson, S., Brix, A. (2005): Weather Derivative Valuation: The Meteorological, Statistical, Financial and Mathematical Foundations, Cambridge University Press, New York, USA. 
25. Lazibat, T., Županić, I., Baković, T. (2009): Vremenske izvedenice kao instrumenti terminskih tržišta, Ekonomska misao i praksa, vol. 18, br.1, str.59-78., Sveučilište u Dubrovniku, Hrvatska.

26. Leggio, K.B. (2007): Using Weather Derivatives to Hedge Precipitation Exposure, Managerial Finance, vol. 33, no.4, pp. 246-252., Emerald Publishing Ltd.

27. Marković, T., Jovanović, M., Ivanović, S. (2012): Vremenski svop kao instrument za upravljanje vremenskim rizicima u proizvodnji pšenice, Ratarstvo i povrtarstvo, vol. 49, str. 1-5., (available at: http://scindeks-clanci.ceon.rs/data/pdf/18213944/2012/1821-39441201001M.pdf)

28. Marković, T. (2013): Vremenski derivati i upravljanje rizikom u poljoprivredi, Monografija, Poljoprivredni fakultet, Novi Sad, Srbija.

29. Müller, A., Grandi, M. (2000a): Weather Derivatives: A Risk Management Tool for Weather-sensitive Industries, The Geneva Papers on Risk and Insurance, vol. 25, no.

2, pp. 273-287. (available at: https://riva-online.com/wp-content/uploads/2012/11/ Grandi-Mueller-Weather-Derivatives.pdf)

30. Müller, A., Grandi, M.(2000b): Weather Derivatives for Protection Against Weather Risks: Speculation Tool or Integral Element of The Risk Management Tools of Weather-sensitive Industries? Geneva Papers on Risk and Insurance: Issues and Practice 25, pp. 273-87, (available at: http://www.munichre.com/publications/ art weather derivates en.pdf.)

31. MunichRe Group (2000): Weather Derivatives, The Geneva Papers on Risk and Insurance, Suisse.

32. Piovani, G., Torluccio, G., Cotugno, M., (2012): Weather Derivatives Market and The Italian Case, European Journal of Social Sciences, vol. 30, no. 3, pp. 352-365.

33. Rao, S. V. D., Thakur, S. (2008): Optimal Hedge Ratio and Hedge Efficiency: An Empirical Investigation of Hedging in Indian Derivatives Market, (available at: https://www.soa.org/library/monographs/other-monographs/2008/april/mono2008-mas08-1-thakur.pdf)

34. Rohrer, M.B. (2004): The Relevance of Basis Risk in the Weather Derivatives Market, Computational Finance and Applications, M.Constantino and C.Brrebbia (Eds.), WTI Press, pp. $67-74$.

35. Russ, R. (2004):Weather Derivatives: Global Hedging Against the Weather, Derivatives Use, Trading and Regulation, vol. 9, no. 4, pp. 293-301.

36. Scott, D., McBoyle, G. (2007): Climate Change Adaptation in The Ski Industry, Mitigation and Adaptation Strategies for Global Change, vol. 12, issue 8, pp. 1411 1431., Springer Science.

37. Shin, C., Nicholls, S., Holecek, D. (2009): Impact of Weather on Downhill Ski Lift Ticket Sales, Journal of Travel Research, vol. 47, no. 3, pp. 359-372., Sage Publications, (available at: http://citeseerx.ist.psu.edu/viewdoc/download?doi=10

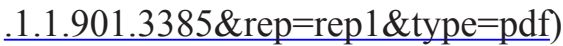


38. Sileo E. (2012): Managing Risk of Ski Resorts with Snow Options, Alma Tourism, vol. 3, no. 6, (available at: https://almatourism.unibo.it/article/view/3723)

39. Simpson, M. C., Gössling, S., Scott, D., Hall, C. M., and Gladin, E. (2008): Climate change adaptation and mitigation in the tourism sector: Frameworks, tools and practices, UNEP, University of Oxford, UNWTO, WMO, Paris, France (available at: http://sdt.unwto.org/sites/all/files/docpdf/ccoxford.pdf)

40. Šperanda, I. (2008): Mogućnosti primjene tehnika terminskog trgovanja na području turizma, Poslovna izvrsnost, vol. 2, br.2, Zagreb, Hrvatska.

41. Systma, D.L., Thompson, G.A. (2002): Weather Risk Management: A Survivor of The Collapse/Demise of U.S. Energy Merchants, R.J. Rudden Associates, Inc. (available at: http://www.rjrudden.com/rudden/media_articles.htm.)

42. Tang, H., Jang, S. (2012): Hedging Weather Risk in Nature-based Tourism Business: An Example of Ski Resorts, Journal of Hospitality \& Tourism Research, vol. 36, no.2, pp. 143-163.

43. Tang, C.H., Jang, S.C. (2016): Weather Risk Management in Ski Resorts: Exploring the Effect of Geographical Diversification on Financial Hedging, Advancing Tourism Research Globally, Tourism Travel and Research Association (avaliable at: http://scholarworks.umass.edu/ttra/2009/Illustrated Papers/2

44. Toeglhofer, C., Eigner, F., Prettenthaler, F. (2011): Impacts of Snow Conditions on Tourism Demand in Austrian Ski Areas, Climate Research, vol. 46, pp.1-14., (available at: http://www.int-res.com/articles/cr_oa/c046p001.pdf)

45. Toeglhofer, C., Mestel, R, Prettenthaler, F. (2012): Weather Value at Risk: On the Measurement of Noncatastrophic Weather Risk, Weather, Climate and Society, vol. 4, pp. 190-199. (available at: http://journals.ametsoc.org/doi/full/10.1175/ WCAS-D-11-00062.1)

46. Tindall, J. (2006) Weather Derivatives: Pricing and Risk Management Applications, Institute of Actuaries of Australia, Australia.

47. Van Lennep, D., Oetomo, T., Stevenson, M., De Vries, A. (2004): Weather Derivatives: An Attractive Additional Asset Class, The Journal of Alternative Investments, vol.7., no. 2, pp. 65-74., Chartered Alternative Investment Analyst Association, USA.

48. Veselinović, J., Marković, T., Đukić, S. (2014): Analysis of Legal and Economic Aspects of Precipitation Weather Derivatives for Serbian Agricultural Sector, Economics of Agriculture, vol. 61, no. 4, pp. 1053-1067., Institute for Economics of Agriculture, Beograd, Serbia.

49. Yang, C., Brockett, P.L., Wen, M. (2009): Basis Risk and Hedging Efficiency of Weather Derivatives, Journal of Risk Finance, vol. 10, issue 5, pp. 517-536.

50. Zapranis, A., Alexandridis, A. (2013): Weather Derivatives Modeling and Pricing Weather-Related Risk, Springer, New York, USA. 


\section{HEDŽING PRIMENOM VREMENSKIH DERIVATA U ZIMSKOM SKI TURIZMU}

\section{Bojan S. Đordević}

\section{Sažetak}

Turizam kaojedna od glavnih pokretačkih snaga ekonomskog razvoja, izloženje mnogim rizicima. Pored čestih fluktuacija deviznih kurseva, cena goriva i transporta, turistička industrija postaje sve osetljivija na vremenske prilike. Jedan od novih instrumenata koji se mogu efikasno upotrebiti za hedžing vremenskog rizika jesu vremenski derivati (forvardi, fjučersi, opcije i svopovi na izabrane vremenske varijable - temperatura, kiša, sneg, vetar itd.).

U ovom radu predstavljamo mogućnost primene vremenskih derivata u zimskom ski turizmu - forvarda na snežne padavine - da bi se hedžovalo poslovanje ski lift operatera. Naše istraživanje bazira se na istorijskim podacima o snežnim padavinama na planini Kopaonik i prihodima ski lift operatera. Pokazaćemo da vremenski derivati mogu biti efektan alat za hedžing vremenskog rizika i smanjenje volatilnosti prihoda kompanija u zimskom ski turizmu u Srbiji.

Ključne reči: vremenski derivati, vremenaki rizik, snežne padavine, hedžing, zimski ski turizam

2 Bojan S. Đorđević, redovni profesor, Fakultet za menadžment Zaječar, Megatrend Univerzitet Beograd, Park Šuma Kraljevica bb, 19000 Zaječar, Tel: +38119430804, e-mail: bojan.djordjevic@,fmz.edu.rs 